\title{
Utilizing of Methane from Polish Hard Coal Mines
}

\author{
Justyna Swolkien \\ Department of Underground Mining, Faculty of Mining \& Geoengineering, AGH University of Science and Technology, Cracow \\ 30-059, Poland
}

Received: August 26, 2014 / Accepted: December 18, 2014 / Published: February 28, 2015.

\begin{abstract}
The methane capturing and its utilization is of great importance for the safety in Polish coal mines. The present study deals with methods which are used to capture and utilize it in hard coal mines. It is of great importance to know that at present, ethane recovered in operating mines is obtained only through drainage systems whose implementation is enforced by health and safety regulations. Because of the fact that the amount of methane released in hard coal mines is expected to rise in years to come, as the methane content of coal seams increases with depth, heavy emphasis should be placed on methane recovery and the practical applications of the captured gas. If mine gas was officially recognised as a primary source for producing "environmentally friendly electricity", would open the perspectives of increasing methane utilization. In addition, the mining industry would gain an incentive to intensify methane recovery. It would be possible to carry out additional work focused on methane drainage from excavations which are not operated. Also, the costs of methane drainage could be included in the costs of energy production, which would undoubtedly have a positive effect on the profitability of mining companies.
\end{abstract}

Key words: Hard coal mines, methane utilization, methane hazard, methane emission.

\section{Introduction}

The number of mines in which methane hazard is present has been on a steady rise as a consequence of mining at deeper levels and continuing to extract deposits with high relative methane content. The occurrence of methane in coal seams is a serious challenge related to work safety. The release of methane occurs during the preparation and extraction of coal seams, as well as during shutdown works. Its presence in coal beds has a negative impact on work safety in underground mining plants, because the gas is released during mining. As a flammable and explosive gas, methane has always been a serious threat in hard coal mines.

Exploitation of coal seams in CMM (coal mine methane) mines requires implementing special technological solutions in order to prevent exceeding safe levels of methane concentration in the mine

Corresponding author: Justyna Swolkien, Ph.D., research fields: mine ventilation, methane control, spontaneous fires and climatic conditions. E-mail: swolkien@agh.edu.pl. atmosphere. The basic method consists in providing adequate ventilation with a strong current of air. The need to reduce methane emissions into excavations in order to prevent exceeding the permissible levels of methane concentration in the air flowing through excavations makes it necessary to apply rock mass methane drainage as a preventive measure. It enables reducing methane emissions into the working area and shifting the areas with the highest concentration of methane to the back of the cavity caused by the extraction [1, 2]. Effective methane drainage in underground excavations not only improves safety, but also increases coal output from mine workings [3].

The review presents methods for recovering methane from coal beds in Polish mines and the possibilities of its utilization. Also, the authors' intention was to draw attention to the necessity of increasing investments in CMM utilization.

\section{Methane Resources in Hard Coal Deposits in Poland}

According to the Balance of Mineral and 
Underground Water Resources in Poland as of 2010, the presence of methane has been confirmed only with respect to the deposits of the Upper Silesian Coal Basin $[4,5]$. To date, no detailed examination has been carried out of the methane conditions in the collieries of the Lower Silesian Coal Basin and of the Lublin Coal Basin; also, the levels of methane concentration in the latter areas are considerably lower, which makes it difficult to assess their economic significance. According to the Balance of Mineral and Underground Water Resources, the prospective geological resources of coal bed methane in the Upper Silesian Coal Basin were estimated at $254 \mathrm{bcm}$ (billions of cubic meters) at the end of 2005. Out of this amount, approximately 150 bcm may be balance recoverable resources. Additionally, off-balance recoverable resources estimated at $38 \mathrm{bcm}$ can be regarded as additional backup. In the Lower Silesian Coal Basin, the prospective resources are 5 bcm. As for the Lublin Coal Basin, the presence of methane has not been excluded, but the few geological studies that have been conducted in this area provide no basis for estimating the available amount.

The confirmed methane resources are present in 52 deposits in the Upper Silesian Coal Basin (Table 1). The balance recoverable resources amount to 89.9 millions of $\mathrm{m}^{3}$, including $28.7 \mathrm{bcm}$ in the extracted areas of 27 developed seams; in addition, the resources currently beyond exploitation, i.e., undeveloped reserve deposits or deep-level deposits below 1,000 m, amount to $65.3 \mathrm{bcm}$. The industrial resources in coal deposits under development have been estimated for 22 deposits and amount to $5.7 \mathrm{bcm}$.

The most widespread form of methane in the hard coal deposits of the Upper Silesian Coal Basin is methane absorbed in the coal beds. Coal bed gas (mine gas) is composed almost entirely of pure methane. Methane resources accumulated in coal beds are closely related to geomechanical properties of coal, the amount of coal and the geological structure of the coal basin. In the mines of Upper Silesia, the highest saturation level is found at the depths ranging from 950 to $1,050 \mathrm{~m}$ below the surface.

\section{Methods of Capturing Coal Bed Methane}

Methane accumulated in hard coal deposits can be captured in the following ways:

- During the extraction of coal (CSM, or coal seam methane);

- From a mine that is no longer in operation (AMM, or abandoned mine methane);

- From undeveloped seams (CBM (coal bed methane) or VCBM (virgin CBM)).

CMM (coal mine methane) is used as a cover term referring to methane captured in both operating and closed mines [6-8]. It can be further subdivided into methane siphoned off in operating mines (methane from active mines), VAM (ventilation air methane) captured from ventilation air and AMM recovered from closed mines [5].

The properties of methane depend on the characteristics of the deposit and the method of recovery, and evolve as the time passes and the conditions of extraction change [9, 10]. The basic constituents of pure gas obtained from CBM are methane, carbon dioxide and possibly nitrogen. Smaller or trace amounts of the following gases can also be identified: carbon oxide, hydrogen, helium, hydrogen sulfide, hydrogen chloride, hydrogen

Table 1 Coal bed methane deposits in Poland as of December 31, 2010 [4].

\begin{tabular}{|c|c|c|c|}
\hline \multicolumn{4}{|c|}{ Coal bed methane in millions of cubic meters } \\
\hline \multirow{2}{*}{ Type } & \multicolumn{2}{|c|}{ Recoverable resources } & \multirow{2}{*}{-Industrial resources } \\
\hline & Balance & Off balance & \\
\hline Total number of confirmed deposits: 52 & $8,998,862$ & $1,690,866$ & $5,690,384$ \\
\hline In the extracted areas of developed hard coal deposits: 27 deposits & $2,872,146$ & 21,407 & 390,427 \\
\hline Including Beyond the extracted areas of coal bed deposits: 16 deposits & $2,700,293$ & 672,886 & 60,400 \\
\hline Deposits of methane as the primary resource: 9 deposits & $3,426,423$ & 995,673 & 118,257 \\
\hline
\end{tabular}


Table 2 Chemical composition of typical mine gas depending on the place of capture.

\begin{tabular}{llll}
\hline Constituent/gas & CBM (\%) & CSM (\%) & AMM (\%) \\
\hline $\mathrm{CH}_{4}$ & $90-98$ & $25-60$ & $60-80$ \\
$\mathrm{CO}_{2}$ & $2-5$ & $1-6$ & $8-15$ \\
$\mathrm{CO}$ & 0 & $0.1-0.4$ & 0 \\
$\mathrm{O}_{2}$ & 0 & $7-17$ & 0 \\
$\mathrm{~N}_{2}$ & $1-8$ & $4-40$ & $5-32$ \\
\hline
\end{tabular}

Table 3 The balance of absolute methane content, amount of ventilation methane, drainage and utilization for the past 11 years [14].

\begin{tabular}{llllllllllll}
\hline Year & 2003 & 2004 & 2005 & 2006 & 2007 & 2008 & 2009 & 2010 & 2011 & 2012 & 2013 \\
\hline $\begin{array}{l}\text { Overall methane emission, in } \\
\text { millions of cubic metres per year }\end{array}$ & 798.1 & 825.9 & 851.1 & 870.3 & 878.9 & 880.9 & 855.7 & 834.9 & 828.8 & 828.2 & 847.8 \\
$\begin{array}{l}\text { Ventilation air methane, in } \\
\text { millions of cubic metres per year }\end{array}$ & 571.0 & 608.7 & 595.8 & 580.8 & 610.1 & 606.7 & 595.9 & 579.0 & 578.6 & 561.5 & 581.7 \\
$\begin{array}{l}\text { Amount of methane captured } \\
\text { through drainage, in millions of } \\
\text { cubic metres per year }\end{array}$ & 227.1 & 217.2 & 255.3 & 289.5 & 268.8 & 274.2 & 259.8 & 255.9 & 250.2 & 266.7 & 276.6 \\
$\begin{array}{l}\text { Amount of utilised methane, in } \\
\text { millions of cubic metres per year }\end{array}$ & 127.8 & 144.2 & 144.8 & 158.3 & 165.7 & 156.5 & 159.5 & 161.1 & 166.3 & 178.6 & 187,7 \\
$\begin{array}{l}\text { Methane emitted into the } \\
\text { atmosphere, in millions of cubic } \\
\text { metres per year }\end{array}$ & 670.3 & 608.7 & 595.8 & 580.8 & 610.1 & 606.7 & 595.9 & 579.0 & 578.6 & 649.6 & 660.1 \\
$\begin{array}{l}\text { Number of hard coal mines } \\
\begin{array}{l}\text { Annual hard coal production, in } \\
\text { millions of Mg }\end{array}\end{array}$ & 41 & 39 & 33 & 33 & 31 & 31 & 31 & 32 & 31 & 31 & 30 \\
\hline
\end{tabular}

fluoride, ammonia and long-chain hydrocarbons. Table 2 shows the chemical composition of typical mine gas depending on the place of capture. The emission of mine gas from coal occurs not only at the stage of extraction, but also later during processing, transport and storage.

In practice, mine gas is obtained mainly in operating coal mines characterized by a high methane content in relation to the existing resources, in abandoned mines, or simultaneously from developed seams and disused mines. In both cases, the cost-effectiveness of methane capture is similar (although obtaining methane from disused mines is slightly less profitable). In Europe, the practice of obtaining methane from virgin coal beds is non-existent, but such operations are implemented, for example, in the United States and Australia [8, 11-13].

As for the utilization of methane captured from ventilation (VAM), e.g., to replace air in combustion engines or gas turbines, practical attempts have so far been made only in Australia [7, 11].

Table 3 presents the evolution of absolute methane content (a sum of ventilation air methane and methane captured through the drainage system) in the Polish mining industry in the period 2003-2013 and the total amount of methane captured through drainage and utilized [6]. In 2012, the annual output of methane from methane-bearing seams amounted to 59.4 million $\mathrm{Mg}$ (75\% of the total output), while the capture in non-methane seams was 19.8 million $\mathrm{Mg}$ ( $25 \%$ of the total output). In 2013, almost 848 million $\mathrm{m}^{3}$ of methane was emitted, which means that the average emission was at the level of $1,813 \mathrm{~m}^{3}$ of methane per minute [14]. The index of specific methane emission in Polish hard coal mining industry reached the value of $11.1 \mathrm{~m}^{3} / \mathrm{Mg}$ (cubic metre of methane per mega gram of mined coal) in 2013, while in 2012 the value was 10.5 $\mathrm{m}^{3} / \mathrm{Mg}$ and in 2001 was $7.1 \mathrm{~m}^{3} / \mathrm{Mg}$. An annual increase of $0.5-0.8 \mathrm{~m}^{3} / \mathrm{Mg}$ has been observed every year.

It is expected that in the years to come methane hazard accompanying exploitation in Polish mines will remain at a steady level. Consequently, methane hazard will continue to be the predominant threat to be 
reckoned by the Polish mining industry. Therefore, the only way to ensure the safety of exploitation will be to adopt adequate preventive measures.

The need to reduce methane emissions into excavations in order to prevent exceeding the permissible methane concentrations in mine air imposed by mining regulations makes it necessary to implement methane drainage based on a system of drainage holes. Effective drainage of coal in underground excavations not only improves safety, but also increases coal output [3, 15].

At present, mine gas is not regarded as a renewable source of energy in Poland, although it could be perceived as such as it is a primary source for producing environmentally "friendly electricity". As a result, the attractiveness of mine gas as an energy source is significantly diminished, because not having the status of a renewable source excludes the possibility of selling energy at preferential prices. As a cogeneration source, mine gas failed to produce the expected economic advantages despite positive environmental impact (reduced emissions). It can be considered a sign of progress that investments in utilizing mine gas can receive preferential treatment (as contributing to environmental protection) [16].

In Germany, producing energy from methane recovered in mines is supported in the same way as renewable energy sources (since 2000) with a guaranteed fixed subsidy to the obtained electricity. This solution has won approval in Europe as an exemplary effective way of responding to the problem.

There is a possibility that the attractiveness of utilizing methane will rise considerably when methane has been included in the EU Emissions Trading Scheme (through a system of certificates). Considering the future cost of buying allowances, the scheme will plunge the Polish hard coal mining industry into permanent unprofitability.

\section{Methods of Methane Drainage of Rock Mass and Their Efficiency in Polish Mines}

The primary objective of preventive measures implemented in mines is to prevent methane concentrations in mining excavations from exceeding the values permitted by the relevant regulations. For this purpose, two basic methods are implemented. The first method consists in supplying air (ventilation) to guarantee that methane concentrations will remain at an adequate level in every place in the mine. This procedure does not always prevent or reduce methane hazard. The second method is methane drainage. Both methods are inseparable and mutually dependent.

The most widespread mining system used in Polish mines is the longwall system, which makes it possible to obtain a relatively high coal output and high advance rates. Absolute methane-bearing capacity can even reach as much as $100 \mathrm{~m}^{3} \mathrm{CH}_{4} / \mathrm{min}$. High coalbed methane content frequently requires using highly effective methane drainage systems during mining. Many different models of methane drainage during longwall mining have been used in Poland as a result of a wide range of factors affecting the choice of an adequate methane drainage system.

The methods of methane drainage which have been used in Polish coal mines up to date, are presented in the Fig. 1.

Methane drainage in development headings due to the hardship and decline of absolute methane-bearing capacity, as well as bringing to the underground headings during drivage right amount of air, in the majority of Polish mines have been abandoned. Instead of that the appropriate quantity of air was delivered to the underground headings to prevent an increase in methane concentration above the prescribed value [2].

Geological properties (porosity, permeability, reservoir pressure, diffusivity) of coal seams, coalbed methane content and low desorption of Polish coal seams results in low gas emission without disturbing the structure of rock-mass. Therefore, the amount of released methane is closely connected with the range and scale of mining activities, both during the development stage and during mining proper [15, 17]. That is way pre-mining drainage is used only 


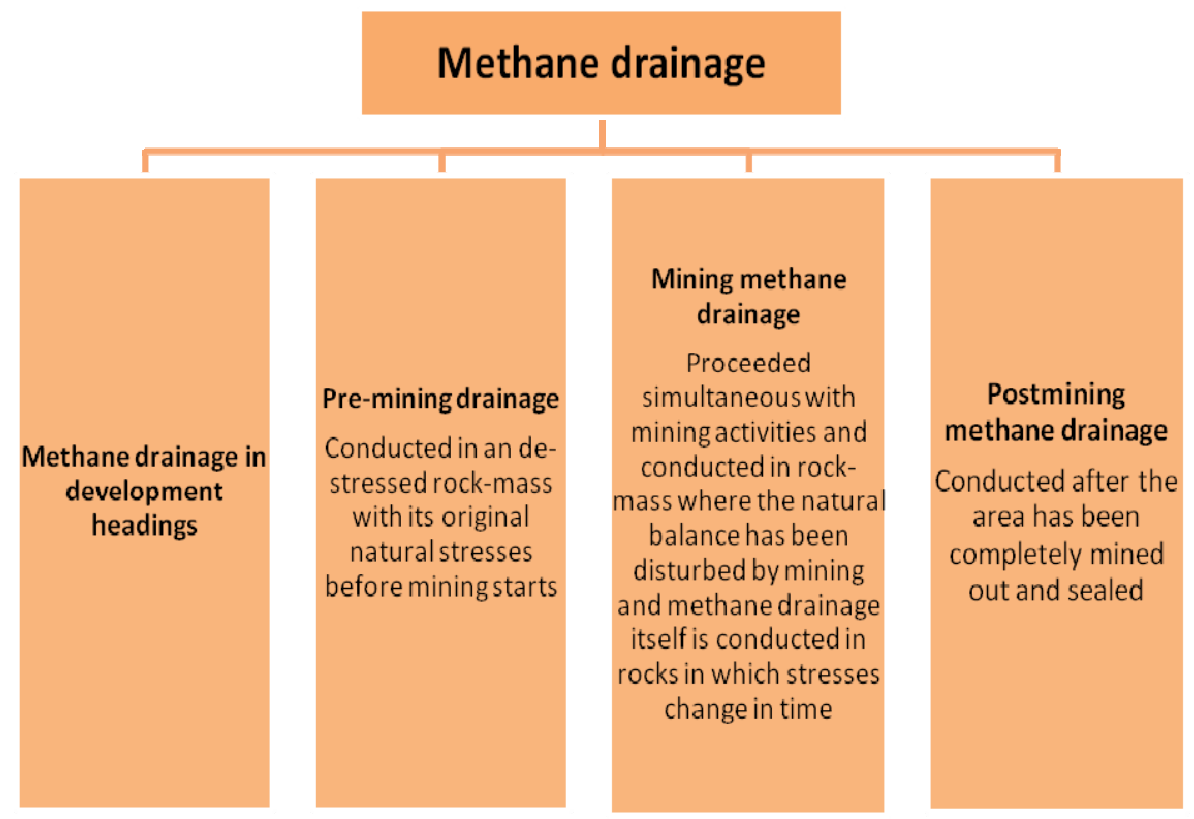

Fig. 1 Division of methane drainage technologies.

sporadically in Polish mines. Low coal permeability results in the low effectiveness of this method.

Another method of methane drainage consists in draining methane from unmined and sealed areas (post-mining drainage). The main reason to start draining methane from sealed areas is a situation in which significant amounts of methane start to gather there. Either the gas may come from coal, which got through to the caving zone, or it may migrate from adjacent coal seams through fissures and fractures. In most cases, methane from the goaf of longwalls with caving is most frequently drained by means of perforated tubes or through drainage boreholes drilled from a return roadway. The disadvantage of this drainage method is that it considerably increases mining costs. On the other hand, the system enables many mining plants to obtain high quality gas that can be utilised later on.

Methane drainage of rock-mass (mining methane drainage) is the most effective method of preventing methane hazard as it reduces the frequency of methane inflows into working areas and prevents or reduces occurrences such as outflows, sudden outbursts of methane and rock [15]. The method that has proved the most efficient is draining methane from rock-mass and goaf of longwalls and transporting it to the surface through separate pipelines, using the negative pressure of drainage station pumps. Although this method ensures the desired parameters of ventilation, it imposes certain requirements concerning the development of methane-bearing coal seams.

The hitherto applied technology of methane drainage involves two methods implemented while exploitation is in progress. The first procedure entails drilling boreholes from ventilation corridors to the decompressed zone at the roof or at the floor of the developed seam. It is the most widespread method of methane drainage used in the Polish mining industry. The position of boreholes and their parameters depend on the characteristics of the exploitation and ventilation systems. The second method involves drilling drainage galleries in overworked or underworked seams.

The adopted method of methane drainage is closely connected with the ventilation system used in a given excavation. The solutions commonly used in mines include the $U$ and $Y$ ventilation systems, while drilling a parallel entry is less frequent $[1,2,18]$. Methane drainage is achieved by using drainage boreholes whose parameters and placement depend on the ventilation system and local conditions related to 
geology and mining. Figs. 2 and 3 present the common methods of drainage implemented in Polish mines.

Fig. 2a shows the placement of drainage boreholes in an air roadway in front of the advancing longwall face in a $U$ ventilation system. Having a sufficient number of drainage boreholes is a real organizational challenge due to the advance of the longwall face and equipment installed in the roadway. Along a relatively short stretch of the upper entry, drilling works should be conducted with sufficient intensity to ensure that a sufficient number of boreholes guarantee the required efficiency of methane drainage. Fig. $2 b$ shows the placement of drainage boreholes in an air roadway in a $\mathrm{Y}$ ventilation system. In such cases, boreholes are drilled behind and in front of the face depending on the absolute methane content. In this case, methane drainage effectiveness is usually greater than that of a $\mathrm{U}$ system. The decisive factor that determines the level of methane capture and therefore the efficiency of methane drainage is the large number of boreholes simultaneously connected to the drainage system with negative pressure (in front of and behind the face). Fig. $2 \mathrm{c}$ shows the placement of drainage boreholes in a ventilation corridor in a $U$ ventilation system with a parallel entry. Fig. 3 presents the structure of a methane drainage system with a drainage gallery. The system involves making a special entry called a drainage (methane) gallery above the mined seam in an undeveloped seam. This heading should be located within a desorption zone in the rock mass.

Although implementing methane drainage significantly increases the exploitation costs, it provides the mining plant with gas whose excellent parameters make it suitable for utilization. At present, there are a number of technologies that enable economically feasible applications of the captured gas.

In recent years, the largest amounts of gas captured through methane drainage in Polish hard coal mines have been obtained from excavations; post-mining gobs were the second most effective place of capture, while methane drainage in longwalls produced the smallest amount. Fig. 4 shows the percentage of the total methane capture in Polish hard coal mines in 2012 obtained in various places of capture [14].

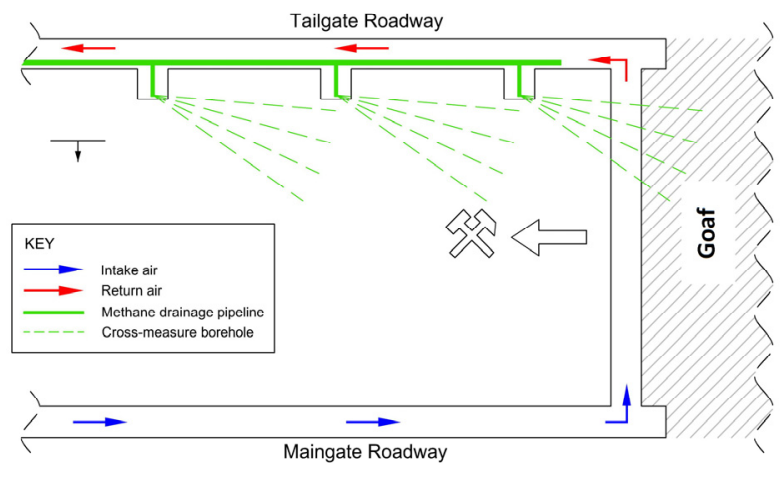

(a)

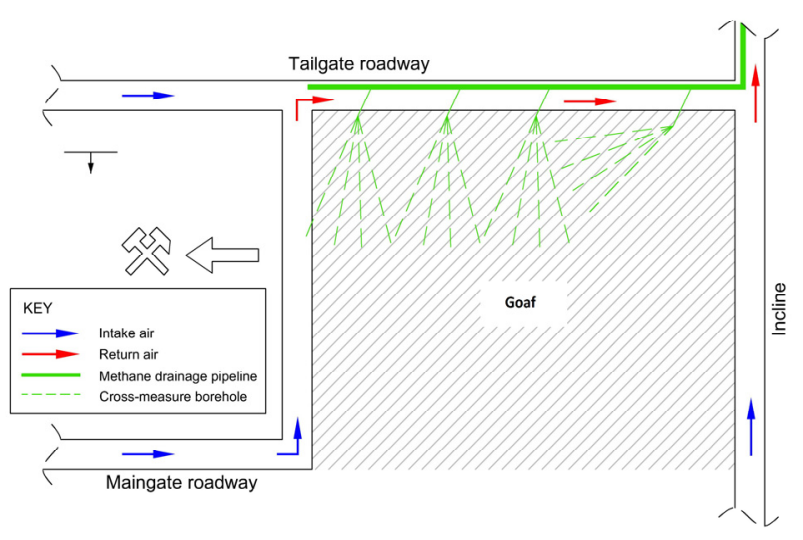

(b)

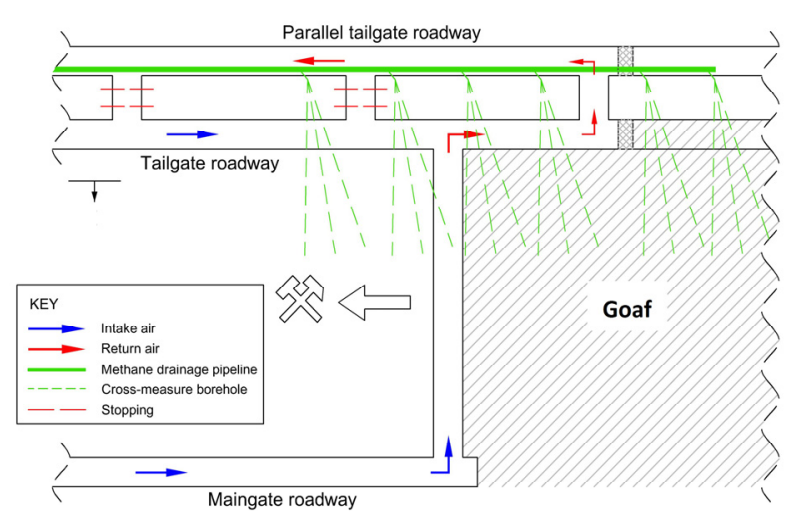

(c)

Fig. 2 The most common systems of ventilation and methane drainage in Polish coal mines: (a) a $U$ ventilation system; (b) a Y ventilation system; (c) a ventilation system with a parallel entry. 


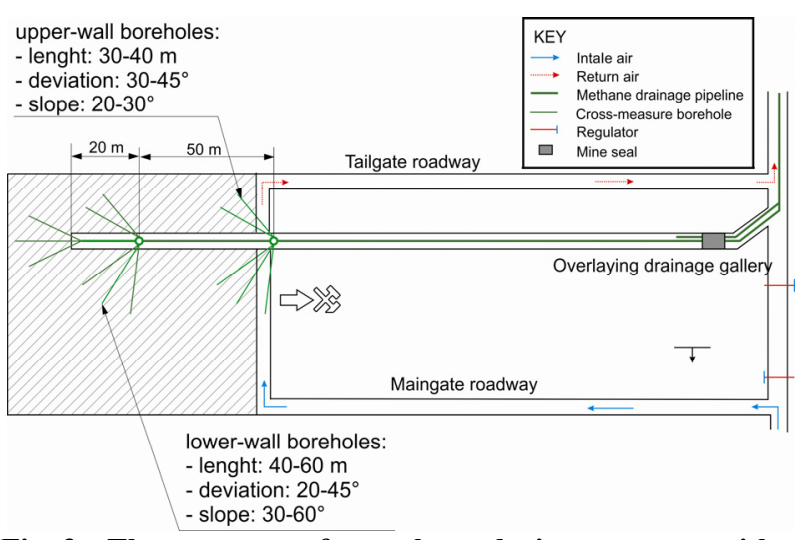

Fig. 3 The structure of a methane drainage system with a drainage gallery.

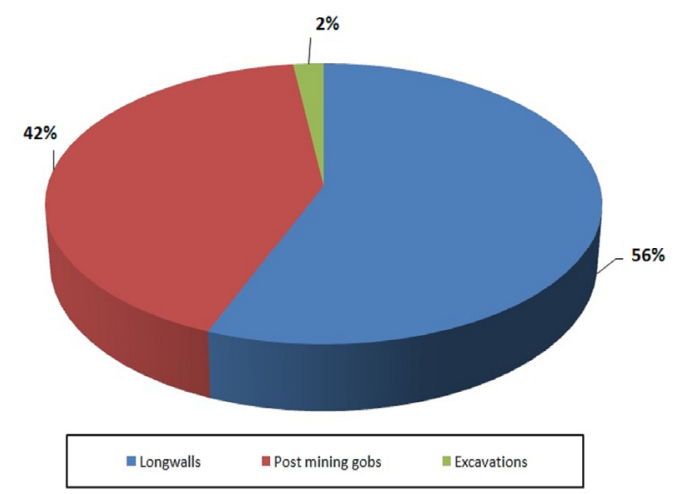

Fig. 4 The percentage of the total methane capture in Polish hard coal mines in 2012 obtained in various places of capture [14].

Table 4 presents the relations between the efficiency of methane drainage in longwalls and the type of the ventilation and drainage systems for the last 10 years [3, 19]. The average efficiency of methane drainage in mining excavations in the years 2003-2012 (Table 4) was $54 \%$ The lowest value of $41 \%$ as reached in longwalls with the lowest absolute methane content ventilated with a $U$ system. The highest average methane drainage efficiency was $64 \%$ and was achieved in longwalls ventilated with system using a parallel entry or overlying drainage gallery. As for longwalls ventilated with a Y system, methane drainage efficiency was $49 \%$. When this system of ventilation is implemented, the air-tightness of boreholes drilled from the ventilation gallery behind the longwall face diminishes over time. This is caused by the progressing degradation of the ventilation gallery and the fact that casing pipes are placed in the immediate proximity of the gob. By contrast, a parallel tail entry leaves a pillar between the two gangways, which make it possible to achieve enduring air-tightness of the drainage boreholes, resulting in a mixture of gases with higher methane concentration.

It should be emphasized that at present, methane captured in operating mines is obtained only using drainage systems whose implementation is enforced by health and safety regulations. In order to increase the degree of methane utilization and the efficiency of methane drainage implemented by mining companies, it is absolutely necessary to include the cost of methane capture in the costs of producing energy.

Table 5 presents changes of absolute methane-bearing capacity and drainage efficiency for several mines which belong to JSW Group in 2011. The methane drainage technologies currently in use enable capturing on average $41 \%$ of methane released during mining operations in coal mines with methane hazard, like in the JSW Group. It should be noticed that this efficiency can vary depending on the coal mine, in less than $30 \%$ in Borynia Coal Mine to almost $62 \%$ in Krupiński Coal Mine. It is important to know that not all coal mines conduct methane drainage to the same extent, mostly because of the fact that emission of methane from certain excavation is changeable. In many cases, conducting methane drainage, due to the low methane emissions is technically difficult and not profitable.

Taking in to consideration coal output from 30 hard coal mines, the average recognition of methane in 2013 was $30 \%$ on the average, while $70 \%$ was removed through ventilation $[3,20]$. It is feasible to increase the percentage of captured methane to $60 \%$ using the currently applied technological solutions, leaving $40 \%$ of methane to be emitted into the atmosphere. The state-of-the-art technologies enable capturing $80 \%$ of methane from low permeability coals extracted in Poland [21]. It is noteworthy that the entire amount of captured methane 
Table 4 The relations between the efficiency of methane drainage in longwalls and the type of the ventilation and drainage systems [3, 19].

\begin{tabular}{llllllllc}
\hline Efficiency of methane drainage $(\%)$ & Average drainage \\
Breakdown & efficiency $(\%)$ \\
\hline Total methane emission $\left(\mathrm{m}^{3} / \mathrm{min}\right)$ & $20-30$ & $30-40$ & $40-50$ & $50-60$ & $60-70$ & $70-80$ & $>80$ & not obtained not obtained 48.7 \\
\hline Longwalls ventilated with a Y system & 52.4 & 56.1 & 49.9 & 46.2 & 57.9 & 63.9 \\
Longwalls with a parallel roadway & 58.0 & 60.1 & 62.2 & 64.2 & 64.5 & 68.3 & 71.5 & 63.9 \\
$\begin{array}{l}\text { and ventilated with a U system } \\
\text { Longwalls ventilated with a U system }\end{array}$ & 40.6 & 38.3 & 48.8 & 64.0 & not obtained not obtained not obtained 41.2 \\
$\begin{array}{l}\text { Longwalls with overlying drainage } \\
\text { gallery and ventilated with a U system }\end{array}$ & 60.2 & 62.6 & 68.4 & 64.7 & 68.6 & 68.8 & 76.0 & 65.5 \\
\hline
\end{tabular}

Table 5 Absolute methane-bearing capacity and drainage efficiency of JSW S.A. coal mines in 2011 [2].

\begin{tabular}{lllll}
\hline \multirow{2}{*}{ Coal mine } & \multicolumn{3}{c}{ Absolute methane-bearing capacity, $\mathrm{m}^{3} \mathrm{CH}_{4} / \mathrm{min}$} & Average drainage efficiency, \% \\
\cline { 2 - 5 } & Ventilation air methane & Amount of drained methane & Total & \\
\hline Borynia & 33.80 & 12.56 & 46.36 & 27.09 \\
Budryk & 63.44 & 25.51 & 88.95 & 28.68 \\
Jas-Mos & 18.65 & 17.35 & 36.00 & 48.19 \\
Krupinski & 49.72 & 80.13 & 129.85 & 61.71 \\
Pniowek & 144.67 & 93.44 & 238.11 & 39.24 \\
Zofiówka & 62.64 & 29.24 & 91.88 & 31.79 \\
JSW S.A. & 372.92 & 258.23 & 631.15 & 40.91 \\
\hline
\end{tabular}

is not utilized mainly because the demand for heating is seasonal. The available amount is used up almost entirely in winter (during the heating season). For this reason, steps should be taken to enable utilizing the surplus of methane for other applications, e.g., to prepare chilled water used to air condition excavations as extraction moves deeper, to produce LNG (liquefied methane) or CNG (compressed methane).

An increase in the level of methane capture in hard coal mines and in the degree of its utilization can only occur when favorable economic conditions are guaranteed.

\section{The Current System of Supporting the Utilization of Methane from Hard Coal Mines}

In accordance with the Polish regulations [22], a system of supporting methane utilization has been created. It consists in issuing Certificates of Origin to electricity produced through high-performance cogeneration in a unit fueled by methane released and recovered during underground mining operations. The scheme applies to operating or closed mines, and the issued confirmations are hereafter referred to as "violet" certificates.

Article 91 Section 1 of the Act of January 8, 2010 [22] contains the following provisions: the fact that energy was produced in the process of high-performance cogeneration is confirmed by a Certificate of Origin, hereafter referred to as cogeneration certificate. Cogeneration certificates for electricity produced in the process of high-performance cogeneration are issued separately for the following types of units:

(1) Supplied with gas fuels or having total installed capacity below $1 \mathrm{MW}$;

(2) Fired with methane released and recovered during underground mining operations in hard coal mines which are active, in the process of decommissioning and decommissioned, or with gas extracted from biomass as provided in Article 2 Section 1 Item 2 of the Act on biocomponents and liquid biofuels.

The violet certificates scheme is based on the so-called Renewable Portfolio Standard of energy produced from methane. The standard consists in imposing on a given entity, such as a producer, a provider or a receiver, the duty to provide or purchase a 
specified amount of energy coming from a source that falls under the support scheme.

In order to ensure adequate functioning of the scheme, a parallel system of Certificates of Origin has been implemented to provide proof that a given amount of energy has been produced in accordance with the requirements.

The President of the Energy Regulatory Office, acting on his prerogative defined in Article 23 Section 2 of the Energy Law Act, introduced the so-called substitute fee per unit, specified in Article 9a Section 8a of the same Act. In 2010 and 2011, the fee was 19.72 USD per MWh, which was the lowest sum allowed, equal to $30 \%$ of the average selling price of electricity in the competitive market (the permissible range specified in the Act being between $30 \%$ and $120 \%$ ).

The costs of methane drainage vary from mine to mine, which is caused by a range of factors such as different geological structures. In 2011, the cost of drainage per unit ranged from 0.06 to $0.09 \mathrm{USD} / \mathrm{m}^{3}$. The cost per unit of methane hazard protection, including also the expenses connected with maintaining methane drainage infrastructure, ranged from 0.39 to $0.6 \mathrm{USD} / \mathrm{m}^{3}$. As a result, the average combined cost of methane recovery per unit was 0.46 $\mathrm{USD} / \mathrm{m}^{3}$ in 2011.

\section{Utilizing the Captured Methane}

The applications of mine methane are presented in Table 6 [22]. The dependence of the applied procedures on the source of mine gas in the process of coal extraction has been taken into account.

While taking into account the infrastructure of gas networks and its relatively limited ability to transport methane recovered from coal seams, it should nevertheless be said that most energy supply networks are located on the premises of the mining plant or in its vicinity. This fact accounts for the possible ways of utilizing the gas obtained through degasification of coal beds in Poland, which include [23, 24]:

- Heat generation for the purpose of heating by burning gas in boilers and installations (e.g., drying rooms);

- Combined generation of electricity and hot water;

- Combined generation of electricity and process steam;

- Combined generation of electricity and the agent needed for drying processes;

- Combined generation of heat, cold and electricity;

- Generation of electricity in combined systems.

In most cases, a gas system is linked to a thermal power plant or a fossil-fuel power station. The functioning of the vast majority of such plants is based on internal combustion engines with pistons because of their high efficiency and relatively small investments needed [24].

The type of supplied gas fuel is important for the functioning of an engine. Not all devices available on the market can be fuelled with gas drained from mines. The decisive factors for the alternate use of fuels are Wobby index, methane number and combustion rate. In most cases, a minimum level of methane concentration is also required. Also, modifications of supply systems and combustion chambers are necessary to enable using mine gas as fuel. These adjustments are usually connected with changes of compression ratio and mean effective pressure; in some cases, they also involve changing the homogenisation degree of the mixture and ignition energy. The changes in construction usually involve the head of the engine, which affects the shape of its combustion chamber. The simplest solutions consist in changing the volume of the combustion chamber and ignition angle. More complex ones involve modifying the supply system, selecting the proper turbulence of the gas mixture, local modifications of the composition of gases in the combustion chamber or increasing the number of spark plugs. Despite these challenges, piston engines are in widespread use in installations powered with special gases. Using gas obtained through methane drainage causes a significant decrease in the power and efficiency of an engine. 
Table 6 The applications of mine methane and their characteristics [28].

\begin{tabular}{|c|c|c|c|}
\hline Technology & $\begin{array}{l}\text { Gas recovered } \\
\text { from ventilation air }\end{array}$ & $\begin{array}{l}\text { Gas recovered from } \\
\text { developed coal seams }\end{array}$ & $\begin{array}{l}\text { Gas recovered from } \\
\text { virgin coal seams }\end{array}$ \\
\hline Tool for recovery & Fans & $\begin{array}{l}\text { Vertical shafts, boreholes in coal } \\
\text { seams (horizontal) }\end{array}$ & Vertical boreholes in coal seams \\
\hline Equipment used & Fans, a system of pipelines & $\begin{array}{l}\text { Boreholes in coal seams and/or } \\
\text { surface equipment, compressors and } \\
\text { pumps }\end{array}$ & $\begin{array}{l}\text { Boreholes in coal seams and/or } \\
\text { surface equipment, compressors and } \\
\text { pumps }\end{array}$ \\
\hline Heating value & $\begin{array}{l}\text { Low (methane content }<1 \% \text { (usually } \\
\text { below } 0.6 \% \text { ) }\end{array}$ & Medium (10-30 MJ/kg) & High (up to $37 \mathrm{MJ} / \mathrm{kg}$ ) \\
\hline Applications & $\begin{array}{l}\text { To Be burned with air in boilers, } \\
\text { piston engines or gas turbines; } \\
\text { conversion to heat or electricity in } \\
\text { reactors (flow-reversal oxidisers) }\end{array}$ & $\begin{array}{l}\text { Energy production; using in gas } \\
\text { distribution networks (after } \\
\text { purification); direct (e.g., industrial) } \\
\text { utilisation }\end{array}$ & $\begin{array}{l}\text { Like the gas recovered from } \\
\text { developed coal seams; a raw } \\
\text { material for the chemical industry }\end{array}$ \\
\hline Availability & $\begin{array}{l}\text { The first batch of technologies } \\
\text { available, the second batch at the } \\
\text { feedback stage }\end{array}$ & Technologies available & Technologies available \\
\hline Applicability & Dependent on local conditions & $\begin{array}{l}\text { Widespread } \\
\text { localisation }\end{array}$ & 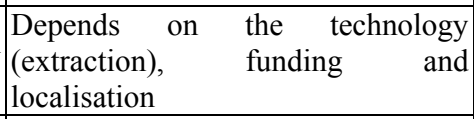 \\
\hline $\begin{array}{l}\text { Degree of methane } \\
\text { reduction }\end{array}$ & $10 \%-90 \%$ & Up to $50 \%$ & Up to $70 \%$ \\
\hline
\end{tabular}

An alternative application of mine gas obtained through methane drainage is its purification and liquefaction to LNG [25-27]. The resulting liquid product consists of $97 \% \mathrm{CH}_{4}$ and $3 \% \mathrm{~N}_{2}$; after regasification, it becomes a fuel whose properties are virtually identical with those of natural gas. The key difference is that gas obtained through methane recovery includes neither higher hydrocarbons nor water, which is eliminated entirely before cryogenic processes are initiated.

The process of liquefaction of recovered methane involves a serious challenge: the necessity to purify the gas before initiating cryogenic processes. The major contaminants include $\mathrm{H}_{2} \mathrm{~S}, \mathrm{Hg}, \mathrm{O}_{2}, \mathrm{CO}_{2}, \mathrm{H}_{2} \mathrm{O}$ and $\mathrm{N}_{2}$. Although nitrogen is separated directly as its condensation temperature is lower than that of methane, other contaminants need to be removed using advanced equipment.

The "contamination" that is the most difficult to remove from gas obtained through methane drainage is oxygen, contained (like nitrogen) in the air pumped by a methane drainage station. The first trial installation in Poland, set up by the Polish LNG Company, is based on the Thermal Oxidation technology, which involves low temperature catalytic combustion of methane in a catalytic reactor $[6,27]$. The catalyst of this reaction is a palladium compound, which enables combustion to take place in temperatures below $500{ }^{\circ} \mathrm{C}$. The temperature is also dependent on the oxygen content in the mixture. Thermal oxidizer, employed in the KWK Krupinski coal mine, was developed to eliminate oxygen content of max. $8 \%$, but trials proved its ability to remove up to $11 \%$. At this point, it is obvious that the higher the oxygen content, the greater the methane loss. Table 3 presents the applications of methane obtained through drainage in the period 2003-2013.

Purifying gas of $\mathrm{H}_{2} \mathrm{~S}$ and $\mathrm{Hg}$ is possible with the use of activated carbon, while $\mathrm{CO}_{2}$ and $\mathrm{H}_{2} \mathrm{O}$ are removed through adsorption. Large amounts of water released in the process are removed through condensation. The cost-efficiency of cogeneration units depends to a large extent on the following factors:

(1) Methane content in the recovered gas;

(2) Cost of electricity supplied to the installation;

(3) The entry price of methane gas;

(4) Economically feasible prices of the final product (LNG).

The cost of electricity is the most prominent figure in the structure of production costs. The peak power demand of an installation with a daily capacity of 
approximately $17 \mathrm{Mg} \mathrm{LNG}$ is $2 \mathrm{MW}$ of electricity.

As an alternative to power network (of the mine or external) supplying the installation, it is possible to use a power generator powered by a gas engine, in which recovered gas is burned as fuel. Such a combination significantly improves the cost-efficiency of the entire undertaking.

Income from selling liquefied methane is strongly correlated to the prices of alternative energy sources. Liquefied methane can be utilized in the so-called blank areas poorly covered by gas distribution networks. Energy-consuming production plants situated in those areas use fuel oils and LPG (liquefied petroleum gas) for technological purposes and to provide social services to their employees. Therefore, the price of liquefied methane has to be competitive in relation to the prices of those fuels and imported LNG.

\section{Conclusions}

The amount of methane released in hard coal mines is expected to rise as the methane content of coal seams increases with depth (the last decade has seen a rise in the amount of methane released from every $\mathrm{Mg}$ of extracted coal by $60 \%$ ) [4, 20]. Therefore, heavy emphasis should be placed on methane recovery and the practical applications of the captured gas.

It should be emphasized that at present, methane recovered in operating mines is obtained only through drainage systems whose implementation is enforced by health and safety regulations.

If mine gas was officially recognised as a primary source for producing "environmentally friendly electricity", it would open the perspectives of increasing methane utilisation. In addition, the mining industry would gain an incentive to intensify methane recovery. It would be possible to carry out additional work focused on methane drainage from excavations which are not operated. Also, the costs of methane drainage could be included in the costs of energy production, which would undoubtedly have a positive effect on the profitability of mining companies.
It is noteworthy that the entire amount of captured methane is not utilized mainly because the demand for heating is seasonal. The available amount is used up almost entirely in winter (during the heating season). For this reason, steps should be taken to enable utilizing the surplus of methane for other applications, e.g., to prepare chilled water used to air condition excavations as extraction moves deeper, to produce LNG or CNG.

\section{References}

[1] Szlązak, N., Borowski, M., and Obracaj, D. 2008. "Directions of Changes in Ventilation System of Longwalls with Attention on Reduction Ventilating Hazards." Mineral Resources Management 24 (1/2): 201-14.

[2] Szlązak, N., Berger, J., Borowski, M., Obracaj, D., Swolkień, J., and Korzec, M. 2012. Methane Drainage Systems of Coal Seams. Cracow: AGH.

[3] Szlązak, N., Berger, J., Borowski, M., Obracaj, D., Swolkień, J., and Korzec, M. 2012. "Effectiveness of Coal Mine Methane Drainage in Polish Mines." Presented at the 29th Annual International Pittsburgh Coal Conference: Coal-Energy, Environment and Sustainable Development, Pittsburgh, USA.

[4] Polish Geological Institute. 2011. Balance of Mineral and Underground Water Resources in Poland as of 31 December 2010. PGI report, Warsaw.

[5] Kotas, A. 1994. Coal-Bad Methane Potential of Upper Silesian Basin. The work of Polish Geological Institute. PGI report, Warsaw, t.142.

[6] Somers, J., and Talkington, C. 2014. "Coal Mine Ventilation Air Methane Mitigation: Global Developments." In the proceedings of the 10th International Mine Ventilation Congress, Sun City, RPA, $139-46$.

[7] Brunner, D. J., Schwoebel, J. J., and Brinton, J. S. 2005. "Modern CMM Drainage Strategies". Presented at the First Western States CMM Recovery and Use Workshop as a part of the EPA Coalmine Methane Outreach Program. Accessed September 13, 2008. http://www.epa.gov/cmop/docs/cmm_conference_apr05/ dan_brunner.pdf.

[8] McFall, K. S., and Wicks, D. 1986. A Geologic Assessment of Natural Gas from Coal Seams in Warrior Basin, Alabama. GRI topical report.

[9] United States Environmental Protection Agency 2009. Coal Mine Methane Recovery. A Prime:- Washington. 430-R-09-013. EPA topical report. Accessed December 10, 
2010. http://www.epa.gov/cmop/docs/cmm_primer.pdf.

[10] United States Environmental Protection Agency 2009. Identifying Opportunities for Methane Recovery at U.S. Coal Mines, Profiles of Selected Gassy Underground Coal Mines.2002-2006. Washington. 430-K-04-003. EPA topical report. Accessed December 10, 2010. http://www.epa.gov/cmop/docs/profiles_2008_final.pdf.

[11] Black, D. J., and Aziz, N. I. 2009. "Developments in Coal Mine Methane Drainage and Utilization in Australia." In Proceedings of the 9th International Mine Ventilation Congress, 445-60.

[12] Fields, H. H., Krickovic, S., and Sainato, A., Zabetakis, M. G., Mining, P., and Safety Research Center and Pa, P. 1973. Degasification of Virgin Pittsburgh Coalbed though a Large Borehole. Bureau of Mines. Bureau of mines report of investigations.

[13] Diamond, W. P. 1994. Methane Control of Underground Coal Mines. Information Circular. Bureau of Mines. United States Department of Interior.

[14] Central Mining Institute. 2013. Annual Reports on the Natural and Technological Hazards in Hard Coal Mining 2002-2011, 2003-2012: Report, Katowice.

[15] Lunarzewski, L. W. 2001. "Gas Drainage Practicies." In Proceedings of the Coal Operators Geotechnology Collequium, 34-44.

[16] Ministers of Environment of the Visegrad Group Countries. 2014. "A List of Concessions for Seeking, Recognition and Extraction of Mineral Beds." Issued by the Ministry of the Environment. Accessed May 12012. http://www.mos.gov.pl/g2/.

[17] Krause, E., and Łukowicz, K. 2004. "Methane Drainage in Polish Hard Coal Mines Achievements and Perspectives." Presented at the 11th International Scientific and Technical Conference Rockbursts 2004, Poland.

[18] Berger, J., Markiewicz, J., and Dołęga, T. 2010. "Influence of Distance of Exploitational Front from Drainage Boreholes on Their Efficiency with Use of the U Ventilation System." Archives of Mining Sciences 55 (3): 561-71.

[19] Szlązak, N., Berger, J., Borowski, M., Obracaj, D., Swolkień, J., and Korzec, M. 2012. "Effectiveness of Coal Mine Methane Drainage in Polish Mines." Presented at the 29th Annual International Pittsburgh Coal Conference: Coal-Energy, Environment and Sustainable Development,
Pittsburgh, USA.

[20] Litwa, P., Respondek, A., and Katan, D. 2014. "Works Safety Improvement in Hard Coal Mines-Methane Hazard Reduction.” In Proceedings of the 10th International Mine Ventilation Congress, Sun City, RPA, 147-54.

[21] Szlązak, N., Obracaj, D., and Swolkień, J. 2014. "Possibilities of Increasing the Effectiveness of Mining Methane Drainage in Conditions of Low Permeability of Coal Seams." Journal of Energy and Power Engineering 8: 1167-76.

[22] The Act of January 8, 2010 on Amending the Energy Law and on Amending Certain Other Acts. A legal act. Warsaw.

[23] Szlązak, N., Tor, A., and Jakubów, A. 2002. “An Analysis of the Capture and Utilization of Methane in the Mines of the Jastrzębska Spółka Węglowa S.A.” In Proceedings of the 2nd School of Mine Ventilation: Zakopane, 07-11 October the Section of Mining Aerology of the Committee of Mining of the Polish Academy of Sciences [et al.], Cracow, 339-55.

[24] Szlązak, N., Borowski, M., Obracaj, D., and Szlązak, A. 2004. "Energy Balance of the Operation of a Combined System of Central Air-Conditioning in 'Pniówek' Coal Mine." AGH Journal of Mining and Geoengineering 28 (1): 85-102.

[25] United States Environmental Protection Agency. 2013. Global Mitigation of Non- $\mathrm{CO}_{2}$ Greenhouse Gases: 2010-2030. Washington. 430-R-13-011 EPA. Accessed April 25, 2014. http://www.epa.gov/climatechange/ Downloads/EPAactivities/MAC_Report_2013.pdf.

[26] United States Environmental Protection Agency.2006. Global Anthropogenic Non- $\mathrm{CO}_{2}$ Greenhouse Gas Emissions: 1990-2030. Washington. 430-R-13-011. EPA topical report. Accessed April 22, 2014. http://www.epa.gov/climatechange/Downloads/EPAactivi ties/GlobalAnthroEmissionsReport.pdf.

[27] United States Environmental Protection Agency 2003. Assessment of the Worldwide Market Potential for Oxidizing Coal Mine Ventilation Air Methane. Washington. 430-R-03-002. EPA. Accessed December 10, 2010. http://www.epa.gov/cmop/docs/ventilation air_methane.pdf.

[28] Skorek, J., and Kalina, J. 2005. Gazowe Uklady Ko Generacyjne. Warsaw: WNT. 